\title{
A small parabolic trough collector as a solar water heater: an experimental study in Ouargla region, Algeria
}

\author{
Djamel Benmenine ${ }^{1}$, Mokhtar Ghodbane ${ }^{2 *}$, Mohammed Elbar Soudani ${ }^{1}$, Haffar Abdelouahed ${ }^{1}$, Amghar \\ Massiv $^{1}$, Nabil Elsharif ${ }^{3}$ \\ ${ }^{I}$ Laboratory for the Development of New and Renewable Energies in Arid Zones (LENREZA), University of Ouargla, ALGERIA \\ ${ }^{2}$ Mechanical Engineering Department, Faculty of Technology, University of Blida 1, ALGERIA \\ ${ }^{3}$ Mechanical Engineering Department, University of Benghazi, LIBYA \\ *Email: ghodbannemokhtar39@yahoo.com
}

\begin{abstract}
This study aims to conduct an experimental thermal examination of a parabolic trough collector in Ouargla region at Algeria, which will be used as a solar water heater. The solar collector was manufactured and then experimentally tested, as its theoretical optical performance was estimated at $75.06 \%$, while the values of its true thermal performance are 10.61, 10.68 and $8.85 \%$ for 13 May, 14 May and 15 May. Although its thermal performance is somewhat low, the studied PTC is effective in heating the water, whereas, using a volumetric flow of 0.011 $l / s$, about 317 liters of water can be heated daily at $42^{\circ} \mathrm{C}$, knowing that the daily average consumption of hot water in a typical house is 250 liters because the Ouargla region is strategically located that receives huge amounts of solar irradiance.
\end{abstract}

Keywords: thermal solar energy, PTC solar collector, solar water heater, solar energy.

Received: 10/10/2020 - Accepted: 20/11/2020

\section{Introduction}

Currently, the world is experiencing an important shift in energy production from fossil fuels to the exploitation of renewable energies, and precisely the solar energy that is expanding its use through the use of various solar collectors (photoelectric [1] and thermal collectors "flat [2], linear [3-6] and point collectors [ $\underline{7}$, 8]"), whereas, the efficiency of these solar collectors can be improved by dispersing nanoparticles in the working fluid [9-11], this will allow to improve its thermophysical properties [12-14]. Moreover, solar collectors have several important uses, including electricity production [15], water desalination [16-18], drying [19], cooking [20], air conditioning [21-24], heating [25-27], and industrial processes [7, 28]. Therefore, the use of solar collectors of all kinds can be an ideal solution to provide the energy needs of regions with abundant solar energy $[29,30]$. One of the most important uses of solar energy now is the heating of water, as solar heaters are a way to exploit the thermal energy generated from the sun's rays in heating water for home, industrial and commercial purposes, and these systems achieve a higher economic feasibility than solar photovoltaic energy, where the household electricity bill can be saved especially If the solar heater is connected to a hot water tank. Since the solar heater heats the water and stores it during the day for use throughout the day (24 hours), unlike the traditional (electric or gas) heater, which can heat at any time of day and night, the size of the solar heater tank is much larger than the traditional water heater tank [3132].

Through this paper, an experimental thermal examination of a solar water heater by adopting a parabolic trough collector (PTC) will be carried out in Ouargla region, Algeria, in order to provide hot water that can be used in many household uses, where in this study, the effect of the mass flow of water inside the receiver tube on the solar heater performance will be discussed. 


\section{Materials and Methods}

The region of Ouargla (Algeria) with latitude $31^{\circ} 58$ 'N, longitude $5^{\circ} 20^{\prime} \mathrm{E}$, altitude $150 \mathrm{~m}$ is known for its agricultural and industrial activity. The need for domestic hot water is generally provided by conventional energy. In our study, we propose a solar, environmental and economical method to obtain hot water for domestic use.

\section{II.1. PTC collector design}

Water PTC was manufactured by the research group on energy conversion of the LENREZA laboratory at Ouargla University (Algeria).

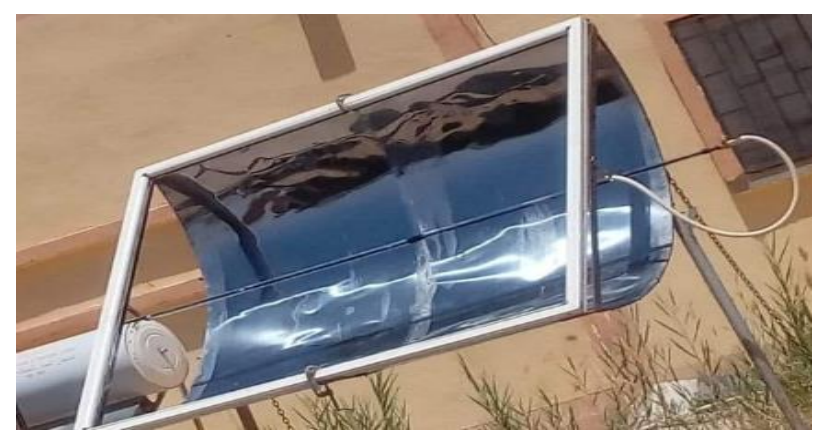

Figure 1. The experimental prototype

The engineering and optical properties of the experimental device are shown in Tables 1 and 2, respectively.

\begin{tabular}{ll}
\multicolumn{1}{c}{ Table 1. PTC engineering properties } & \\
\hline Dimension & Value \\
\hline Absorber tube diameter (inner) & $0.0142 \mathrm{~m}$ \\
\hline Absorber tube diameter (outer) & $0.016 \mathrm{~m}$ \\
\hline Focal length & $0.2 \mathrm{~m}$ \\
\hline Glass diameter (inside) & $0.0175 \mathrm{~m}$ \\
\hline Glass diameter (outer) & $0.02 \mathrm{~m}$ \\
\hline Mirror length & $2 \mathrm{~m}$ \\
\hline Mirror opening width & $1.6 \mathrm{~m}$ \\
\hline Reflector opening area & $2.88 \mathrm{~m}^{2}$ \\
\hline
\end{tabular}

The PTC was placed on two identical steel supports $1.25 \mathrm{~m}$ long oriented north-south so that the PTC can follow the movement of the sun from east to west.

\begin{tabular}{|l|l|} 
Table 2. PTC optical properties \\
\hline Parameter & Value \\
\hline Absorptivity of absorber tube & 0.94 \\
\hline Emissivity of absorber tube & 0.14 \\
\hline Emissivity of glass tube & 0.935 \\
\hline Reflectivity of mirror & 0.935 \\
\hline Transmittivity of glass tube & 0.92 \\
\hline
\end{tabular}

\section{II.2. Measuring instruments}

For the determination of the instantaneous thermal behavior of the PTC, there are parameters must be measured. The various parameters measured and the measuring instruments used are:

Temperatures: three calibrated K-type thermocouples were installed for temperature measurement on different parts of the PTC system, where the thermocouple locations are shown in Figure 2. Solar irradiance: as shown in Figure 2, a solarimeter with an accuracy of $( \pm 5 \%)$ was used to measure solar irradiation during the experiments.

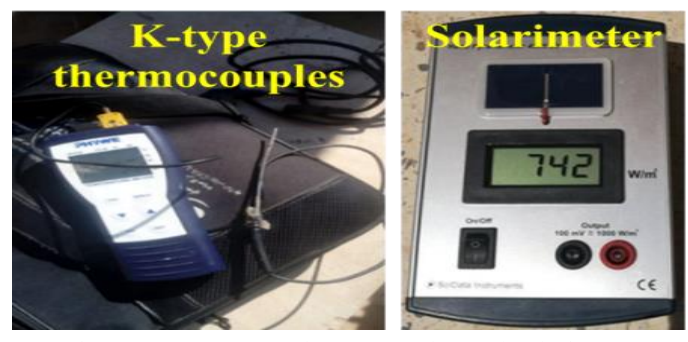

Figure 2. K-type thermocouples and solarimeter

\section{Results and Discussion}

\section{III.1. Experimental set up}

As shown in Figure 3, the solar water heater is composed of a cold-water source, pump, small PTC solar collector and heated water tank, where the system is equipped with the following measuring devices: a solarimeter and three k-type thermocouples. Regarding thermocouples, they are placed as follow:

- $\quad \mathrm{T}_{\mathrm{in}}$ : at the entrance to the PTC absorber tube to measure the cold-water temperature coming from the cold source;

- Tout: at the outlet of the PTC absorber tube to measure the hot water temperature coming out of the PTC collector;

- $\mathrm{T}_{\mathrm{Abs}}$ : to measure the absorber tube temperature.

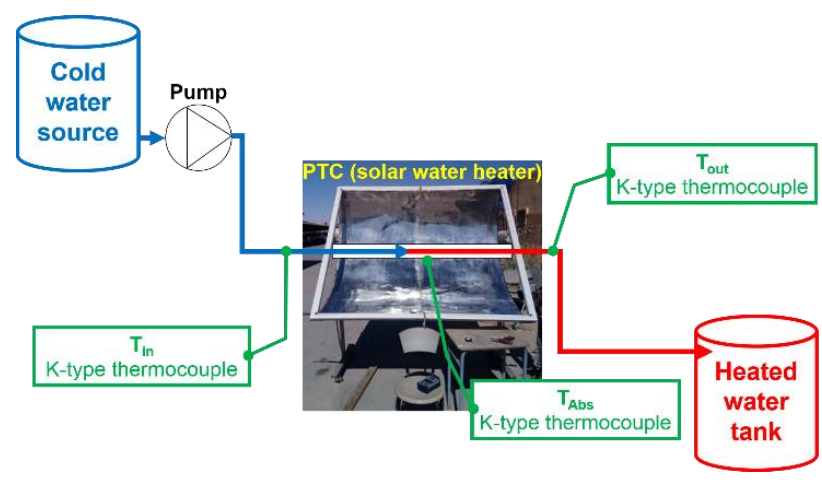

Figure 3. The experimental installation 
Several experiments were carried out in the open air behind the physics laboratories at Ouargla University for three days from 06/05/2019 until 09/05/2019. The PTC solar heater has been tested on the basis of three scenarios, and they are:

\section{First scenario}

The main axis of the PTC was directed from north to south in order to follow the solar movement from east to west with a manual tracking system, where the temperature of the water is measured when entering and leaving the PTC solar collector, as the water volumetric flow inside the receiver tube is constant $\left(Q_{v 1}^{\cdot}=\right.$ $0.011 \frac{L}{s}$ ) and the effect of weather data for May 13, 2019 on the thermal behavior of the system.

\section{Second scenario}

In this scenario, which was completed on May 14, 2019, the PTC was set to the south at an angle of 30 degrees to the horizon, then the solar irradiance and temperatures were measured as was done in the first scenario, as the volumetric flow did not change $\left(Q_{v_{1}}^{\cdot}=\right.$ $\left.Q_{v 2}=0.011 \frac{L}{s}\right)$

\section{Third scenario}

The third scenario was completed on May 15, 2019. The settings for this scenario are the same as those for the second scenario, but the volumetric flow value is less, i.e., the PTC was set to the south at an angle of 30 degrees to the horizon, then the solar irradiance and temperatures were measured as was done in the first scenario, as the volumetric flow did not change $\left(Q_{v 3}^{\cdot}=\right.$ $\left.0.0071 \frac{L}{s}\right)$.

\section{III.2. Results analysis}

The daily variation in solar irradiance measured using the solarimeter on the PTC plane during the test days is given in Figure 5, where it can be deduced from the change of the curves of Figure 4 that the average solar irradiance for days 13 May, 14 May and 15 May is as follows 680, 540 and $494 \mathrm{~W} / \mathrm{m}^{2}$, respectively.

Regarding the change of water inlet temperature " $\mathrm{T}_{\mathrm{in}},\left({ }^{\circ} \mathrm{C}\right)$ ", it is shown in Figure 5 , as the field of its change is between $28.2^{\circ} \mathrm{C}<\mathrm{T}_{\text {in }}<29.5^{\circ} \mathrm{C}$.

Regarding the change of water outlet temperature " $\mathrm{T}_{\text {out }},\left({ }^{\circ} \mathrm{C}\right)$ ", it is shown in Figure 6, where the average water outlet temperature for days 13 May, 14 May and 15 May is as follows 43.38, 40.03 and $41.56{ }^{\circ} \mathrm{C}$ respectively.

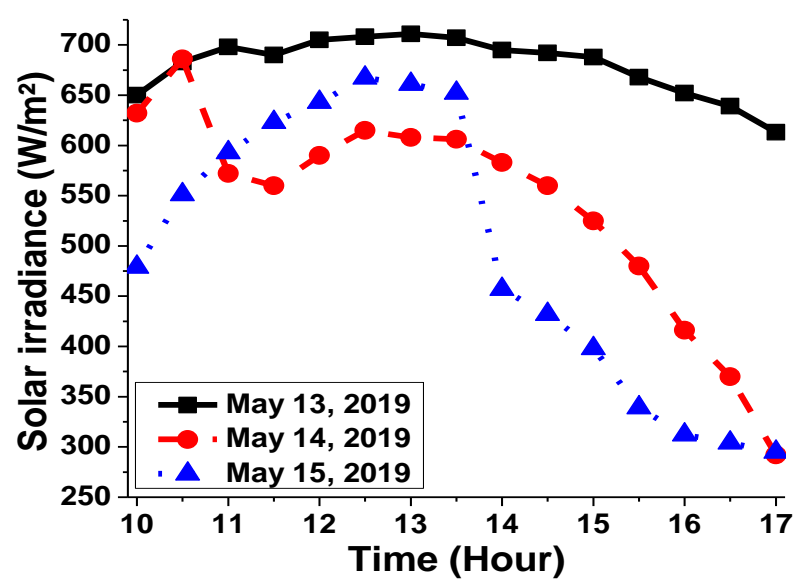

Figure 4. Measured solar irradiance values

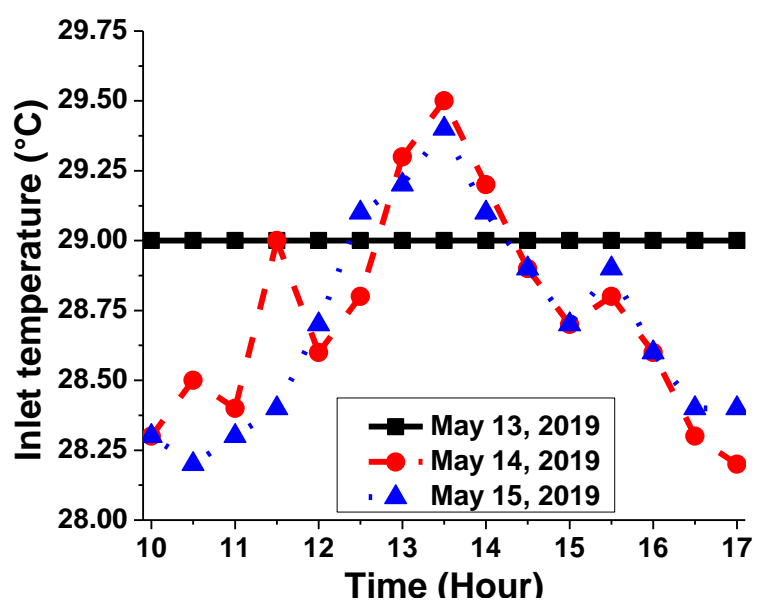

Figure 5. Measured water inlet temperature values

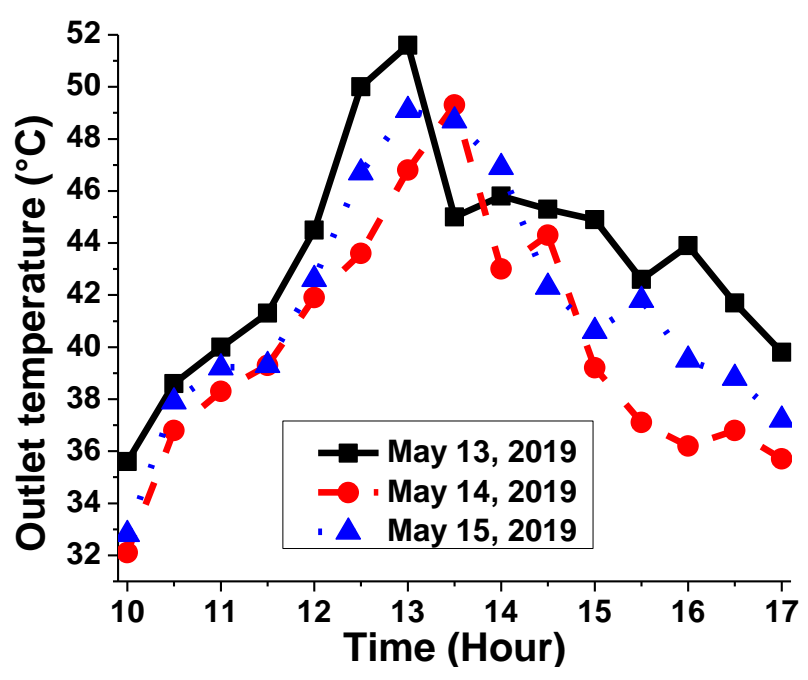

Figure 6. Measured water outlet temperature values 
Concerning the change in PTC thermal efficiencies, it is illustrated in Figure 7, as its average values for days 13 May, 14 May and 15 May is as follows $10.61,10.68$ and $8.85 \%$ respectively.

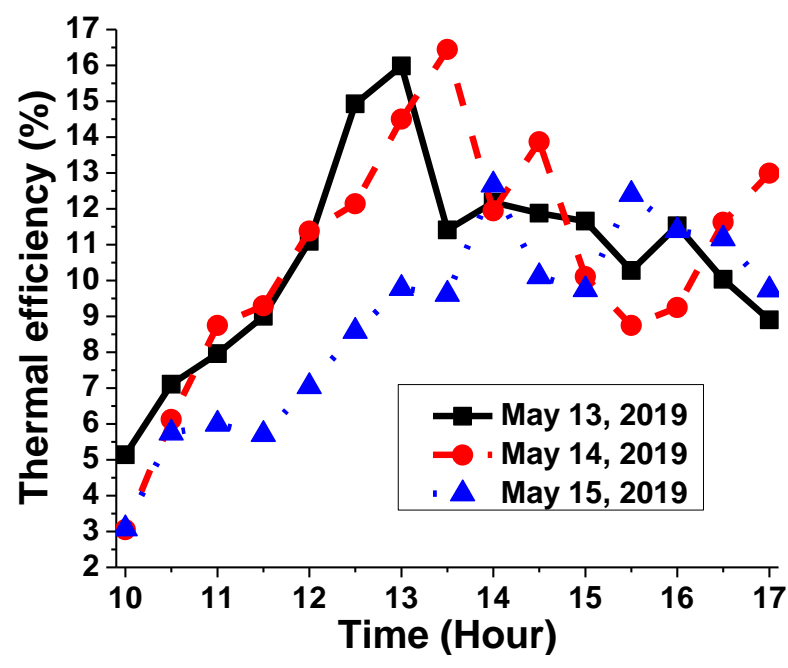

Figure 7. Thermal performance evaluation of the PTC solar heater

Despite good values for solar irradiance recorded on experimental days, it is noticeable that the PTC thermal performance is somewhat low due to the lack of good selection of the PTC focal length $(\mathrm{F}=0.2 \mathrm{~m})$, knowing that the theoretical optical performance of the studied PTC according to its optical properties is $75.06 \%$. According to the geometrical dimensions of the PTC used, the focal distance should be equal to $0.7411 \mathrm{~m}$. therefore, the focal distance of the studied PTC must be adjusted by changing it from $0.2 \mathrm{~m}$ to $0.7411 \mathrm{~m}$, after which the solar water heater will significantly improve in all energetic aspects.

\section{Conclusion}

This study made it possible to determine the water PTC performances, where the operating principle, as well as the parameters influencing the PTC performance have been identified and defined. Through experimental work conducted on the device, it was concluded:

- The theorical optical performance of the studied PTC is $75.06 \%$;

- The amount of instantaneous solar irradiance has a direct effect on the thermal performance of the system, when the amount of radiation increases, the thermal performance values of the system increase directly with it (direct relationship);

- The inlet-outlet temperature gradient $\left(\Delta \mathrm{T}_{\text {out-in }}\right)$ becomes more and more important throughout the studied day until reaching $14.373,11.29$ and $12.86{ }^{\circ} \mathrm{C}$ for 13 May, 14 May and 15 May, respectively;

- The mean values of real thermal performance of the studied PTC are 10.61, 10.68 and $8.85 \%$ for 13 May, 14 May and 15 May, respectively. These values of PTC thermal performance are rather low due to the failure of the absorber tube at the appropriate focal distance $(\mathrm{F})$, which is estimated at 0.7411 according to the dimensions of the studied PTC;

- With a volumetric flow of $\left(\dot{Q_{v}}=0.011 \frac{L}{s}\right)$, about 317 liters of water can be heated daily at $42^{\circ} \mathrm{C}$, knowing that the daily average consumption of hot water in a typical house is 250 liters;

- With a volumetric flow of $\left(\dot{Q_{v}}=0.0071 \frac{L}{s}\right)$, about 317 liters of water can be heated daily at $42^{\circ} \mathrm{C}$, knowing that the daily average consumption of hot water in a typical house is 250 liters.

Moreover, it should be noted that the clear sky tests lasted only three days, which remains insufficient for establishing the characteristics of the PTC studied. Indeed, it would be interesting to conduct performance tests including changes in focal distance, climatic disturbances (ambient temperature, wind speed, climate change of the season) and changes in operating conditions such as withdrawal of water from tanks, etc.

\section{References}

[1] A. Peinado-Gonzalo, A. Pliego-Marugán, F. P. GarcíaMárquez, "Survey of maintenance management for photovoltaic power systems", Renewable and Sustainable Energy Reviews, Vol. 134, 2020, pp. 110347.

[2] E. Vengadesan, R. Senthil, "A review on recent developments in thermal performance enhancement methods of flat plate solar air collector", Renewable and Sustainable Energy Reviews, Vol. 134, 2020, pp. 110315.

[3] E. Bellos, "Progress in the design and the applications of Linear Fresnel Reflectors - A critical review", Thermal Science and Engineering Progress, Vol. 10, 2019, pp. 112-137.

[4] M. Ghodbane, E. Bellos, Z. Said, B. Boumeddane, A. K. Hussein, L. Kolsi, "Evaluating energy efficiency and economic effect of heat transfer in copper tube for small solar linear Fresnel reflector", Journal of Thermal Analysis and Calorimetry, 2020.

[5] Mokhtar Ghodbane, Evangelos Bellos, Zafar Said, Boussad Boumeddane, Abderrahmane Khechekhouche, Mohsen Sheikholeslami, Ziad M. Ali., "Energy, Financial and Environmental investigation of a direct steam production power plant driven by linear Fresnel 
solar reflectors", Journal of Solar Energy Engineering, Vol. 143, No2, 2020, pp. 021008.

[6] M. Ghodbane, B. Boumeddane, Z. Said, E. Bellos, "A numerical simulation of a linear Fresnel solar reflector directed to produce steam for the power plant", Journal of Cleaner Production, Vol. 231, 2019, pp. 494-508.

[7] E. Bellos, C. Tzivanidis, "Solar concentrating systems and applications in Greece - A critical review", Journal of Cleaner Production, Vol. 272, 2020, 122855.

[8] M. Ghodbane, D. Benmenine, A. Khechekhouche, B. Boumeddane, "Brief on Solar Concentrators: Differences and Applications", Instrumentation Mesure Metrologie, Vol. 19, No 5, 2020, pp. 371-378.

[9] E. Bellos, C. Tzivanidis, "Multi-criteria evaluation of a nanofluid-based linear Fresnel solar collector", Solar Energy, Vol. 163, 2018, pp. 200-214.

[10] M. Ghodbane, Z. Said, A. A. Hachicha, B. Boumeddane, "Performance assessment of linear Fresnel solar reflector using MWCNTs/DW nanofluids", Renewable Energy, Vol. 151, 2020, pp. 4356.

[11] Z. Said, M. Ghodbane, L. S. Sundar, A. K. Tiwari, M. Sheikholeslami, B. Boumeddane, "Heat transfer, entropy generation, economic and environmental analyses of linear Fresnel reflector using novel rGOCo3O4 hybrid nanofluids", Renewable Energy, Vol. 165(Part 1), 2021, pp. 420-437.

[12] E. Bellos, Z. Said, C. Tzivanidisa, "The use of nanofluids in solar concentrating technologies: A comprehensive review", Journal of Cleaner Production, Vol. 196, 2018, pp. 84-99.

[13] E. Bellos, C. Tzivanidis, A. Papadopoulos, "Enhancing the performance of a linear Fresnel reflector using nanofluids and internal finned absorber", Journal of Thermal Analysis and Calorimetry, vol. 135, no 1, 2019, pp. 237-255.

[14] A. K. Hussein, M. Ghodbane, Z. Said, R. S. Ward, "The Effect of the Baffle Length on the Natural Convection in an Enclosure Filled with Different Nanofluids", Journal of Thermal Analysis and Calorimetry, 2020.

[15] O. Behar, "Solar thermal power plants - A review of configurations and performance comparison", Renewable and Sustainable Energy Reviews, Vol. 92, 2018, pp. 608-627.

[16] A. Khechekhouche, B. Benhaoua, A. M. Manokar, R. Sathyamurthy, A. E. Kabeel, Z. Driss, "Sand dunes effect on the productivity of a single slope solar distiller," Heat and Mass Transfer, Vol. 56, 2020, pp. 1117-1126.

[17] A. Khechekhouche, A. E. Kabeel, B. Benhaoua, M. E. H. Attia, E. M. S. El-Said, "Traditional solar distiller improvement by a single external refractor under the climatic conditions of the El Oued region, Algeria", Desalination and Water Treatment, Vol. 177, 2020, pp. 23-28.

[18] A. Khechekhouche, Z. Driss, B. Durakovic, "Effect of heat flow via glazing on the productivity of a solar still", International Journal of Energetica, Vol. 4, No 2, 2019, pp. 54-57.

[19] Patchimaporn Udomkun, Sebastian Romuli, Steffen Schock, Busarakorn Mahayothee, Murat Sartas, Tesfamicheal Wossen, Emmanuel Njukwe, Bernard Vanlauwe, Joachim Müller., "Review of solar dryers for agricultural products in Asia and Africa: An innovation landscape approach", Journal of Environmental Management, Vol. 268, 2020, 110730.

[20] Mohamad Aramesh, Mehdi Ghalebani, Alibakhsh Kasaeian, Hosein Zamani, Giulio Lorenzini, Omid Mahian, Somchai Wongwises, "A review of recent advances in solar cooking technology", Renewable Energy, Vol. 140, 2019, pp. 419-435.

[21] E. Bellos, I. C. Theodosiou, L. Vellios, C. Tzivanidis, "Investigation of a novel solar-driven refrigeration system with ejector", Thermal Science and Engineering Progress, Vol. 8, 2018, pp. 284-295.

[22] E. Bellos, C. Tzivanidis, "Optimum design of a solar ejector refrigeration system for various operating scenarios", Energy Conversion and Management, Vol. 154, 2017, pp. 11-24.

[23] E. Bellos, C. Tzivanidis, "Parametric analysis and optimization of a cooling system with ejectorabsorption chiller powered by solar parabolic trough collectors", Energy Conversion and Management, Vol. 168, 2018, pp. 329-342.

[24] M. Ghodbane, B. Boumeddane, A. Khechekhouche, D. Benmenine, "Study of a solar air conditioning system with ejector", International Journal of Energetica, Vol. 5, No 1, 2020, pp. 14-21.

[25] M. Ghodbane, B. Boumeddane, N. Said, "A linear Fresnel reflector as a solar system for heating water: theoretical and experimental study", Case Studies in Thermal Engineering, Vol. 8(C), 2016, pp. 176-186.

[26] M. Ghodbane, B. Boumeddane, N. Said, "Design and experimental study of a solar system for heating water utilizing a linear Fresnel reflector", Journal of Fundamental and Applied Sciences, Vol. 8 No 3, 2016, pp. 804-825.

[27] Z. Said, M. Ghodbane, A. A. Hachicha, B. Boumeddane, "Optical performance assessment of a small experimental prototype of linear Fresnel reflector", Case Studies in Thermal Engineering, Vol. 16, 2019, 100541.

[28] A. Kasaeian, E. Bellos, A. Shamaeizadeh, C. Tzivanidis, "Solar-driven polygeneration systems: Recent progress and outlook", Applied Energy, Vol. 264, 2020, 114764.

[29] M. Ghodbane, B. Boumeddane, "Estimating solar radiation according to semi empirical approach of Perrin de Brichambaut: application on several areas with different climate in Algeria", International Journal of Energetica, Vol. 1, No 1, 2016, pp. 20-29.

[30] M. Ghodbane, B. Boumeddane, and A. K. Hussein, "Performance analysis of a solar-driven ejector air conditioning system under El-Oued climatic conditions, 
Algeria", Journal of Thermal Engineering, Vol. 7(1), 2021, pp. 172-189.

[31] M. Ghodbane, "Étude et optimisation des performances d'une machine de climatisation a éjecteur reliée à un concentrateur solaire " $\mathrm{PhD}$ in Energy and Thermal Systems, Saad Dahleb University of Blida 1, Algeria: www.univ-blida.dz, Thesis available to the Library of the Faculty and the Central Library of the University, 2017.

[32] M. Ghodbane, B. Boumeddane, "A parabolic trough solar collector as a solar system for heating water: a study based on numerical simulation", International Journal of Energetica, Vol. 2, No 2, 2017, pp. 29-37. 